\title{
Sustainable Design Approaches in Malaysia's Traditional Mosques and Houses
}

\author{
Mohd Farid Mohamed \\ Department of Architecture and Built Environment, Faculty of Engineering and Built \\ Environment, Universiti Kebangsaan Malaysia, 43600 Bangi, Selangor, Malaysia \\ faridmohamed@ukm.edu.my
}

\begin{abstract}
The traditional Malaysian mosque and Malay house concepts have been naturally developed for hundreds of years and proven to provide sustainable solutions for building in Malaysia, a country with a hot and humid climate. However, the fast pace of modern development has negatively affected the acceptance of the traditional building concept, especially in the current development of houses and mosques. However, the success of the sustainable design approaches in the traditional Malaysian buildings to ensure sustainable development for hundreds of years has been forgotten. As a result, mainstream modern design concepts have become a contributor to deteriorating environmental conditions due to various factors, including increased energy consumption. Hence, it is crucial to understand the sustainable design approach in traditional Malaysian buildings' design and appropriately apply it to modern building design. Therefore, this study aimed to outline sustainable approaches in traditional mosques and Malay houses in Malaysia. The methodology used in this study was a combination of literature review and site observation on the selected case studies. Six main case buildings were selected for the traditional buildings, including three case studies for the traditional house and three for traditional mosques. This study found a long list of sustainable approaches in traditional Malaysian Mosques and Malay houses. The list of the approaches can be used as an initial reference or guideline in designing new modern buildings in Malaysia, mainly buildings with passive design strategies that contribute to sustainable Malaysia.
\end{abstract}

Keywords: Sustainable approaches, traditional, mosque, house

\section{Introduction}

The traditional Malaysian mosque and Malay house concepts have been naturally developed for hundreds of years and proven to provide sustainable solutions for building in Malaysia, a country with a hot and humid climate. However, the fast pace of modern development has negatively affected the acceptance of the traditional building concept, especially in the current housing development and large mosques.

The success of the sustainable design approaches in the traditional Malaysian buildings to ensure sustainable development for hundreds of years has been forgotten. As a result, mainstream modern design concepts have become a contributor to deteriorating environmental conditions, especially in suburban and urban areas.

Hence, it is crucial to understand the sustainable design approach in traditional

\author{
Malaysian buildings design and \\ appropriately apply it to modern building \\ design. Therefore, this study aimed to outline \\ sustainable approaches in traditional \\ mosques and Malay houses in Malaysia. \\ Understanding the sustainable \\ approaches of traditional is essential due to \\ various factors, including to ensure good or \\ acceptable indoor thermal comfort and air \\ quality. For example, poor building design, \\ which leads to poor indoor thermal comfort \\ will, subsequently, lead to a dependent on \\ mechanical approach for thermal comfort \\ such as a need to install an air conditioning \\ system. This action will lead to higher energy \\ consumption and will negatively impact our \\ environment. \\ For example, according to Ashrifra et al. \\ (2019), referring to Table 1, a simple strategy \\ such as the application of greater opening size \\ (increased by $4.5 \%$ ) for natural ventilation
}


will reduce the indoor temperature, which

will improve the indoor thermal comfort.

Table 1: Predicted indoor temperature at the living and dining areas for a detached low-cost house in Malaysia for two conditions: open window and closed window (Ashrifa et al., 2019)

\begin{tabular}{|l|l|l|l|}
\hline No. & Condition & Description & Temperature $\left({ }^{\circ} \mathrm{C}\right)$ \\
\hline 1. & Closed windows/doors $(12.00 \mathrm{pm})$ & Base model & 33.6 \\
\cline { 4 - 4 } & & Larger window by $4.5 \%$ & 31.6 \\
\hline 3. & Open windows/doors $(12.00 \mathrm{pm})$ & Base model & 31.5 \\
\cline { 4 - 4 } & & Larger window by $4.5 \%$ & 31.2 \\
\hline 4. & &
\end{tabular}

Various sustainable design approaches can be learned from the traditional mosques and Malay houses. Many sustainable approaches are commonly found in the traditional mosques and Malay houses throughout Peninsular Malaysia (Yuan, 1987; Surat, 2016a; Nasir, 1985; Hashim \& Nasir, 2011; Surat et al., 2012; Hosseini, Mursib, \& Raja Shamninan, 2016; Surat, 2016b; Mohammad Yusoff \& Mohamed, 2017; Mohamed, 2018a; Mohamed, 2018b; Surat, 2018; Japlus \& Mohamed, 2018; Izahar \& Mohamed, 2018). Some of the approaches are large window opening, wide roof overhang, built on stilts with concrete or stone base, steep roof, area with open space, opening at roof attic, roof made of leaves or clay, opening on the wall, natural construction materials, oriented towards the qibla, open floor plan, plan with a small width (for houses), modular plan, rain harvesting, difference floor levels, seating area below the house, construction using wood joint, more than one entrance, connecting space between two indoor spaces, flooring with gaps, and high indoor spaces. With the list of sustainable approaches outlined earlier, it is crucial to investigate the list against the real traditional buildings to understand the approaches further and to determine which approaches are commonly found in traditional buildings throughout all states in Peninsular Malaysia.

\section{Research Methodology}

The methodology used in this study is a qualitative approach that combines the extraction of information through literature review and investigation through site observation on the selected case studies. Six case buildings were selected for the traditional buildings, including six case studies for traditional houses and six for traditional mosques. All the case studies are located in Peninsular Malaysia (West Malaysia)

The selected traditional mosques were Kampung Laut Mosque (Kelantan), Kampung Tuan Old Mosque (Terengganu), and Kampung Hulu Mosque (Melaka). Whereas, the selected traditional houses are from Melaka, Kelantan, and Terengganu.

After the completion of the visits to the traditional mosques and Malay houses, and the list of sustainable approaches of the traditional buildings was outlined, simple pilot studies were made to a mosque with passive design strategies and a passively designed modern home. This investigation was an initial or a pilot study for future research in applying the sustainable approaches of traditional buildings into modern buildings.

\section{Discussion}

Various sustainable design approaches can be learned from the traditional mosques and Malay houses. The author visited six traditional Malaysian mosques and six traditional Malay houses, covering six states in Peninsular Malaysia. However, the author only included three traditional mosques (Figures 1 to 3) and three traditional Malay houses (Figures 4 to 6 ). 

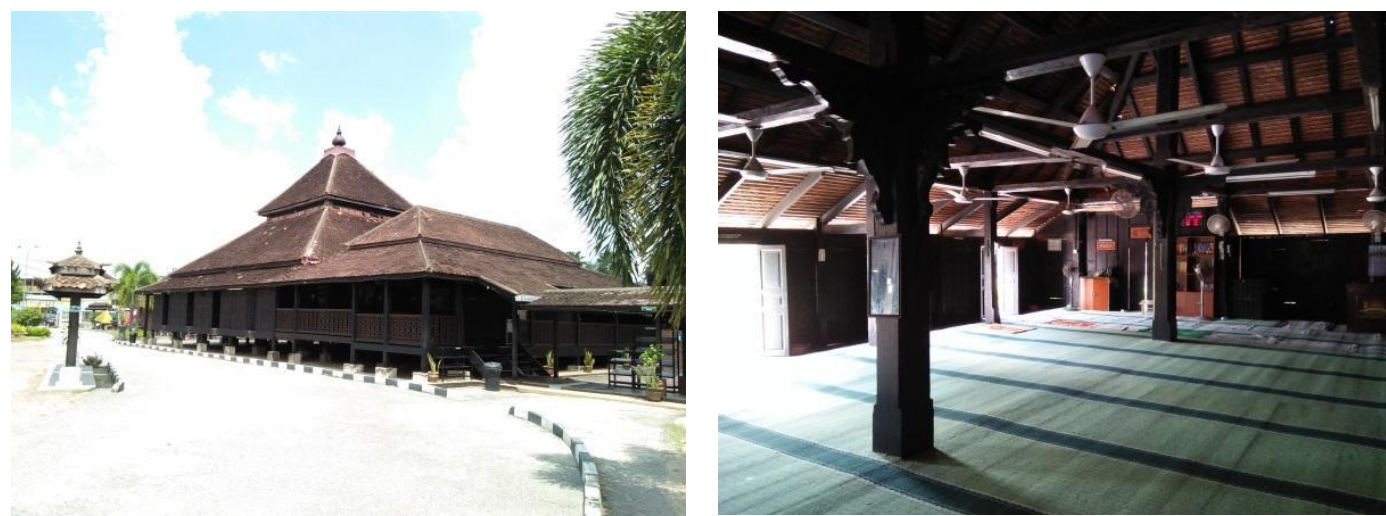

Figure 1: Exterior (left) and interior (right) of Kampong Laut Mosque, Kelantan
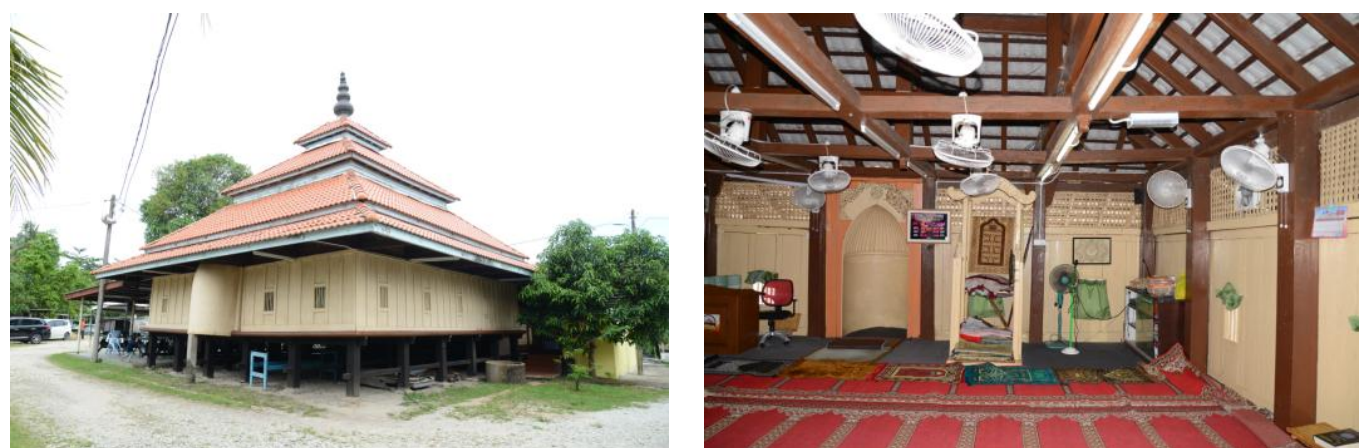

Figure 2: Exterior (left) and interior (right) of Kampung Tuan Old Mosque, Terengganu.
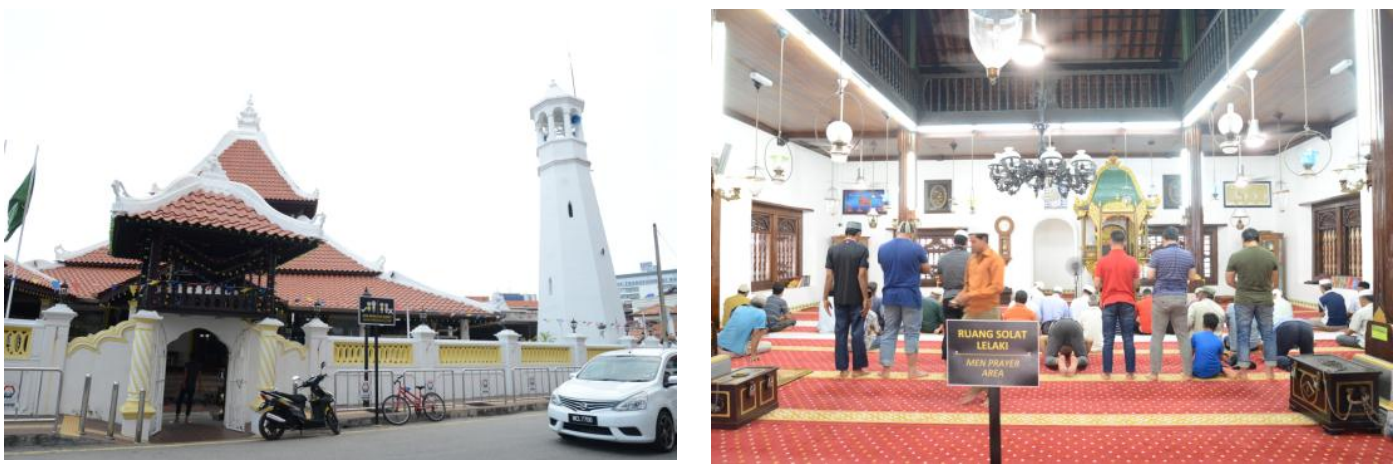

Figure 3: Exterior (left) and interior (right) of Kampung Hulu Mosque, Melaka

Figures 1 to 3 show three old mosques in Malaysia. Kampung Laut Mosque is the oldest mosque in Malaysia. It is believed that the mosque was constructed in 1676 (A. Aziz, 2016). It has a three-tier pyramidal roof and rectangular plan. The mosque was constructed mainly with timber as the main material, and the floor level was raised a few feet above the ground. The photos were taken while the mosque is in Nilam Puri, Kelantan, and currently is disassembled to be relocated to its original site in Kampung Laut, Kelantan.
The second mosque is Kampung Tuan Mosque, which is located in Kemaman, Terengganu, about 300 kilometers south of Kampung Laut Mosque. Similarly, the mosque was constructed using timber as the main material. The interesting features of the mosque are it has a rectangular plan, it does not have as many window openings as Masjid Kampung Laut, and it has a three-tier pyramidal roof.

The third mosque is Kampung Hulu Mosque, which, according to the official note at the mosque, was built in 1720 (some say 1728). It is the oldest or the second oldest 
mosque in Melaka, which was constructed around the same time as Masjid Peringgit (1726). The mosque was constructed during the reign of the Dutch. It was constructed around 50 years after the construction of Kampung Laut Mosque; however, the main material for the construction is concrete/brick wall. It has a square floor plan with a dimension of $12 \times 12$ meters (A. Aziz, 2016). It has a three-tier roof, similar to Kampung Laut Mosque.
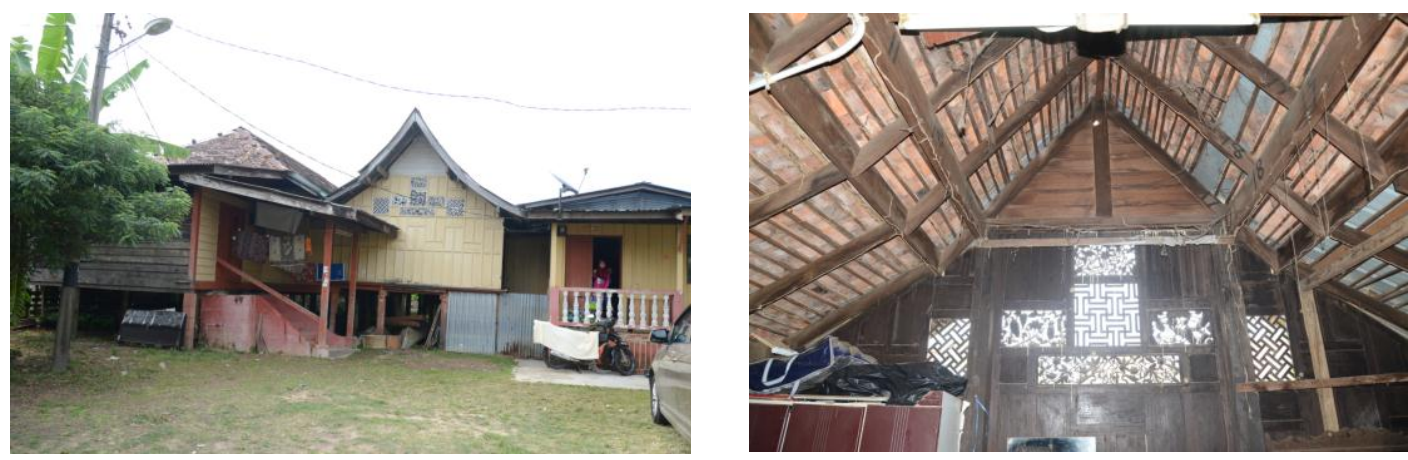

Figure 4: Exterior (left) and interior (right) of Malay traditional house of Kelantan
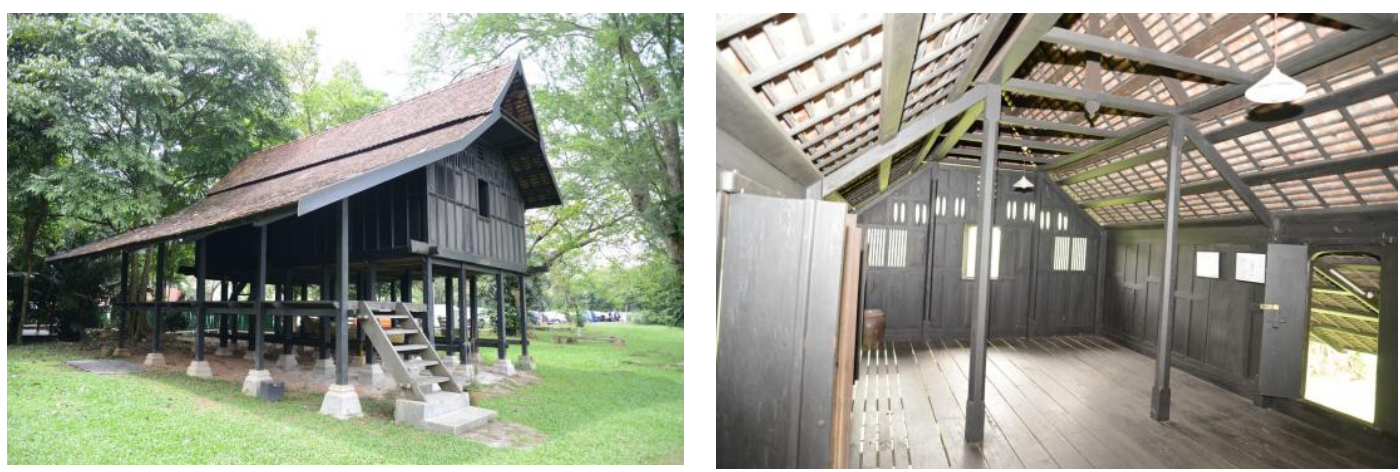

Figure 5: Exterior (left) and interior (right) of Malay traditional House of Terengganu
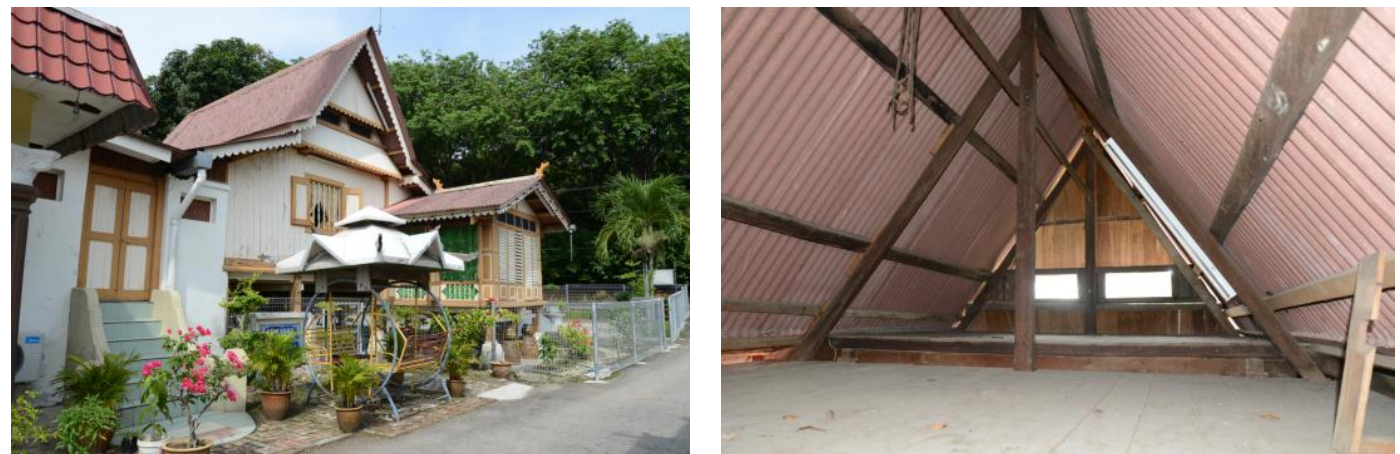

Figure 6: Exterior (left) and interior of attic space (right) of Malay traditional House of Melaka.

Figure 4 shows Kelantan's Malay traditional house located at Kota Bharu, the capital city of Kelantan. The original unit was located in the middle (painted in yellow) and was extended on both left and right sides (on the front and rear facades). It can be observed that the house does not have a window on the wall; however, the timber wall is decorated with nice carvings that allow natural lighting and ventilation. According to the occupant who takes care of the house, the house's age is more than 100 years; however, she is unsure of the exact year the house was built. 
The second house is the Terengganu's traditional house typically found in Terengganu (Figure 5). The house was relocated from Terengganu to Universiti Putra Malaysia, Selangor. The design has similarities to the traditional Kelantan house (Figure 4). The house has a large veranda at the front of the house, and the roof overhang is deep, which protects the veranda from direct sunlight and rainwater. The main floor finish height from the ground is also higher compared to Kelantan's (Figure 4) and Melaka's house (Figure 6).

Figure 6 shows a Melaka's traditional Malay House, which, according to the owner, is over 150 years old. Originally, the house has two almost similar units, the main house (rumah ibu) with a veranda at the front and kitchen unit (rumah dapur) at the back, constructed with timber. Both houses are connected with an internal courtyard. However, now, the rear kitchen house has been replaced with a new unit with concrete flooring. The interesting element of the Melaka's house is habitable attic space similar to other traditional houses in Negeri Sembilan and Perak. In Terengganu and Kelantan, this habitable attic space does not usually exist in a small traditional house.

Based on the discussion earlier, including the literature review and the fieldworks completed by the author for twelve traditional buildings ( 6 mosques and 6 houses), the common sustainable approaches in the traditional mosques and Malay houses are listed in Table 2 .

Table 2: Architectural design approaches of the sustainable traditional mosques and Malay

\begin{tabular}{|c|c|c|}
\hline \multicolumn{3}{|r|}{ Houses. } \\
\hline No. & Approaches & Description \\
\hline 1. & Large window opening & $\begin{array}{l}\text { A large window opening improves natural ventilation and } \\
\text { lighting. It also allows a view of the outside, thus improving } \\
\text { visual comfort. }\end{array}$ \\
\hline 2. & Wide roof overhang & $\begin{array}{l}\text { The wide roof overhang protects the building and its occupants } \\
\text { from rain and direct sunlight, and at the same time, protects the } \\
\text { rain from hitting and damaging the timber wall. }\end{array}$ \\
\hline 3. & $\begin{array}{l}\text { Built on stilt with } \\
\text { concrete or stone base }\end{array}$ & $\begin{array}{l}\text { The approach helps to overcome floods and acts as protection } \\
\text { from wild animals and insects. It also helps to protect the timber } \\
\text { column from the humidity of the ground and at the same time } \\
\text { provide greater privacy to the occupants. }\end{array}$ \\
\hline 4. & Steep roof & $\begin{array}{l}\text { The steep roof helps to speed up the flow of rainwater and } \\
\text { remove the dirt from the roof. The steep roof also provides hot } \\
\text { air removal opportunities and provides an attic for possible } \\
\text { additional space for occupants or storage. }\end{array}$ \\
\hline 5. & $\begin{array}{l}\text { Area with open space } \\
\text { (without a full wall) }\end{array}$ & $\begin{array}{l}\text { It is common for a traditional house to have an open space with } \\
\text { good natural ventilation and lighting, such as a veranda or } \\
\text { balcony (serambi and anjung) that acts as a multifunctional } \\
\text { space for various events. Like the traditional mosque, such a } \\
\text { space known as a balcony or veranda (ruang limpah) is designed } \\
\text { to be around the main praying hall. }\end{array}$ \\
\hline 6. & $\begin{array}{l}\text { Opening and ventilation } \\
\text { gaps at the roof (or roof } \\
\text { attic) }\end{array}$ & $\begin{array}{l}\text { It is common to have opening and ventilation gaps in the roof } \\
\text { (roof attic), which allow for natural ventilation and daylight to } \\
\text { penetrate the indoor environment. }\end{array}$ \\
\hline 7. & $\begin{array}{l}\text { Roof made of leaves or } \\
\text { clay (singgora) }\end{array}$ & $\begin{array}{l}\text { In both traditional mosques and houses, a roof plays an essential } \\
\text { element for indoor thermal comfort. It is common to find a roof } \\
\text { made of leaves or clay (singgora) that acts as a good heat } \\
\text { insulator that reduces heat transfer into the house and does not } \\
\text { absorb much heat from solar radiation. }\end{array}$ \\
\hline 8. & $\begin{array}{l}\text { Opening on wall other } \\
\text { than window and door } \\
\text { (i.e., wooden } \\
\text { carving/timber louver) }\end{array}$ & $\begin{array}{l}\text { Other than timber and doors, there are other types of opening in } \\
\text { traditional mosques and houses, such as wooden carvings and } \\
\text { timber louvers. These elements on the wall also allow for } \\
\text { additional natural ventilation and daylighting. }\end{array}$ \\
\hline
\end{tabular}




\begin{tabular}{|c|c|c|}
\hline 9. & $\begin{array}{l}\text { Natural construction } \\
\text { materials (i.e., timber, } \\
\text { bamboo, bertam, clay, } \\
\text { and granite) }\end{array}$ & $\begin{array}{l}\text { Normally, indigenous and abundantly found materials, such as } \\
\text { timber, bamboo, and bertam trees, are used for traditional } \\
\text { mosques and houses. These materials are good heat insulators } \\
\text { and do not absorb much heat from solar radiation. Clay and } \\
\text { granite are also commonly available locally. Clay is used for the } \\
\text { roof, while granite is used as the base of timber columns. }\end{array}$ \\
\hline 10. & Open floor plan & $\begin{array}{l}\text { In some traditional mosques and houses (especially single } \\
\text { module houses or rumah bujang), interior spaces, such as main } \\
\text { praying hall and main house (rumah ibu), are commonly } \\
\text { designed to be a naturally ventilated open plan. }\end{array}$ \\
\hline 11. & Small width floor plan & $\begin{array}{l}\text { This approach may not be the criterion of a traditional mosque } \\
\text { because it is designed for many occupants. However, it is } \\
\text { common in a traditional house to have a rectangular, small width } \\
\text { floor plan. This layout encourages good natural ventilation and } \\
\text { optimizes daylighting for sufficient indoor use. }\end{array}$ \\
\hline 12. & Modular floor plan & $\begin{array}{l}\text { Usually, a traditional mosque only has a single form design with } \\
\text { (or without) a balcony or veranda surrounding it and connected } \\
\text { to other supporting building elements. However, the house's } \\
\text { character is different, where it has to cater to the family's } \\
\text { growth. Thus, the modular floor plan design is common with the } \\
\text { first unit known as the main house (rumah ibu). An additional } \\
\text { module is added later for various reasons such as increased } \\
\text { family members. }\end{array}$ \\
\hline 13. & $\begin{array}{l}\text { Rain harvesting and use } \\
\text { of water well }\end{array}$ & $\begin{array}{l}\text { Use of water well is common for domestic water uses in } \\
\text { traditional houses and mosques such as shower, irrigation, } \\
\text { ablution, and cleaning. Rain harvesting is also a common } \\
\text { approach as a source of water. However, this approach is more } \\
\text { common in large traditional mosques due to large roof sizes } \\
\text { (such as mosques in Melaka and Kedah), but not in the small } \\
\text { traditional house. }\end{array}$ \\
\hline 14. & Different flo & $\begin{array}{l}\text { Different floor levels help to differentiate between various } \\
\text { purposes of spaces. The different level is to suit timber joint } \\
\text { construction of various connecting spaces, and at the same time, } \\
\text { it allows ventilation through the gap between floors. }\end{array}$ \\
\hline 15. & $\begin{array}{l}\text { Seating area underneath } \\
\text { the house }\end{array}$ & $\begin{array}{l}\text { Traditional mosque typically does not have a high ground to } \\
\text { floor finish height that allows activities underneath. However, } \\
\text { for traditional Malay houses in certain states, particularly } \\
\text { Terengganu and Kedah, the space underneath the floor has } \\
\text { enough head clearance as a social space and multifunctional } \\
\text { area. }\end{array}$ \\
\hline 16. & $\begin{array}{l}\text { Construction using wood } \\
\text { joint (tanggam/mortise } \\
\text { and tenon) }\end{array}$ & $\begin{array}{l}\text { Jointing technique (tanggam/mortise and tenon) of wood is for } \\
\text { stronger construction and easy to assemble and disassemble. The } \\
\text { construction system does not use any steel nails. This approach } \\
\text { allows flexibility for relocating the building to another location. }\end{array}$ \\
\hline 17. & $\begin{array}{l}\text { Multiple entrances and its } \\
\text { design }\end{array}$ & $\begin{array}{l}\text { In the case of a traditional house, it usually has more than one } \\
\text { entrance. The purpose is to separate men and women entrances } \\
\text { while gathering for various activities and purposes. It also eases } \\
\text { the access for the occupants of the house. In the case of a } \\
\text { traditional mosque, it is typical to have many entrances around } \\
\text { the praying hall to allow for easy access by the occupants, such } \\
\text { as Kampung Hulu Mosque. However, in some traditional } \\
\text { mosques, the entrance (s) is only located at the back of the main } \\
\text { praying hall. }\end{array}$ \\
\hline 18. & $\begin{array}{l}\text { Internal courtyard and } \\
\text { connecting space (selang) }\end{array}$ & $\begin{array}{l}\text { Usually, an internal courtyard does not exist in a traditional } \\
\text { mosque. However, in two-module traditional houses (main }\end{array}$ \\
\hline
\end{tabular}




\begin{tabular}{|c|c|c|}
\hline & & $\begin{array}{l}\text { house and kitchen unit), the units are connected with a courtyard } \\
\text { or a walkway (selang), which provide a naturally ventilated and } \\
\text { lit open interior space for various activities such as chatting, } \\
\text { hanging clothes, and drying food. }\end{array}$ \\
\hline 19. & $\begin{array}{l}\text { Flooring with gaps (lantai } \\
\text { jarang) }\end{array}$ & \\
\hline 20. & $\begin{array}{l}\text { High floor to ceiling/roof } \\
\text { height }\end{array}$ & $\begin{array}{l}\text { A high indoor space provides more efficient natural ventilation } \\
\text { to improve indoor thermal comfort. It also leads to better indoor } \\
\text { visuals and a more comfortable feeling for the occupants. }\end{array}$ \\
\hline 21. & Habitable attic space & $\begin{array}{l}\text { This space is generally found in traditional houses, not a } \\
\text { mosque. This space is for an additional floor area that acts as a } \\
\text { multipurpose room, such as hiding from the enemy, bedroom } \\
\text { (especially for daughters), and storage space. }\end{array}$ \\
\hline 22. & Building orientation & $\begin{array}{l}\text { Due to the religious factor, mosques are constructed towards the } \\
\text { qibla. Similarly, some traditional Malay houses are also } \\
\text { constructed in this direction. However, other factors also } \\
\text { influence the house orientation, such as site condition (river, } \\
\text { road, and neighboring house). }\end{array}$ \\
\hline 23. & $\begin{array}{l}\text { Located close to a water } \\
\text { source such as river }\end{array}$ & $\begin{array}{l}\text { It is common to find a mosque or traditional house close to a } \\
\text { river as a source of water for various purposes, such as to take } \\
\text { ablution in a mosque and domestic use for houses. The close to } \\
\text { the river also provides access to river transportation, which is a } \\
\text { common alternative to land/road transportation. }\end{array}$ \\
\hline 24. & $\begin{array}{l}\text { Bare finish construction, } \\
\text { without paint (timber) }\end{array}$ & $\begin{array}{l}\text { Material with a natural finish without the need for chemical paint } \\
\text { could harm the environment. The natural finish also provides } \\
\text { better aesthetics value and low maintenance cost. }\end{array}$ \\
\hline 25. & Multiple layer roof & $\begin{array}{l}\text { Multiple layer roof allows gaps between the roof, leading to the } \\
\text { infiltration of fresh air and removing hot air that improves indoor } \\
\text { thermal comfort. Gaps between the roofs also allow natural } \\
\text { lighting to lit up the attic or indoor spaces. }\end{array}$ \\
\hline 26. & No ceiling & $\begin{array}{l}\text { Mosques and traditional Malaysian houses (without habitable } \\
\text { attic space) usually do not have an indoor ceiling, giving a high } \\
\text { indoor open space with better air circulation and thermal } \\
\text { comfort. }\end{array}$ \\
\hline
\end{tabular}

A simple comparison is made to the modern mosque and house's current design based on the list outlined in Table 2. A simple pilot study was made on the two buildings with the list in Table 2. For the mosque, the

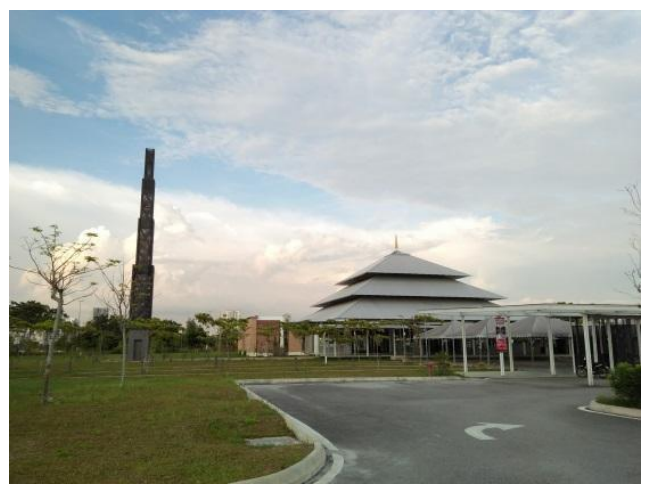

Figure 7: Exterior (left) and interior (right) of recently constructed Masjid Cyberjaya 10 at Cyberjaya Selangor. selection criteria must adopt a passive design strategy for indoor thermal comfort. Like the selected modern house, the house has to apply passive design strategies for internal thermal comfort.

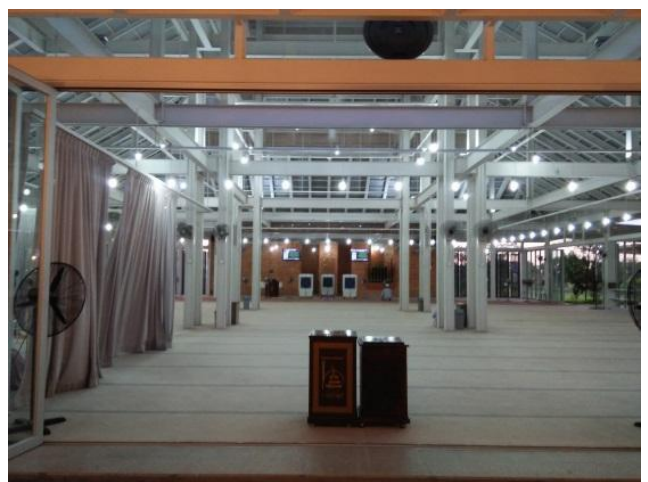



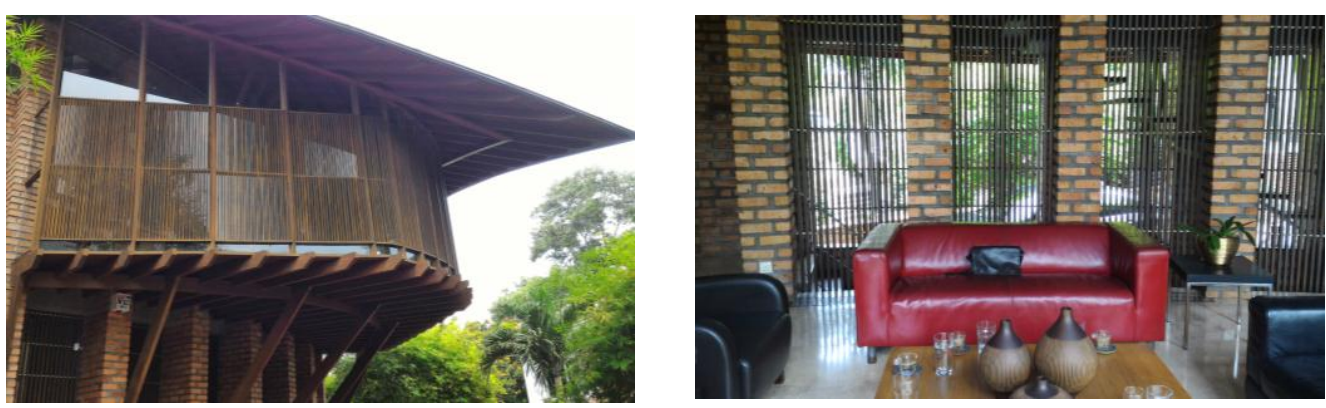

Figure 8: Exterior (left) and interior (right) of modern house design by Wooi Architect

The selected modern mosque is Cyberjaya 10 Mosque (Figure 7), the second mosque built in Cyberjaya. The public knows it as a modern mosque with a resemblance to the typical Malaysian traditional mosque. Whereas the selected modern home is the house designed by Wooi Architect, an awardwinning architecture practice (Figure 8). The house is known for its bare finish materials, mainly constructed with reinforced concrete, red clay brick, and excellent combination with timber as another main construction and finish material.

While mosques do not use timber as the main material, it has adopted the traditional three-tier pyramid roof structure, square floor plan, no ceiling, and abundant natural ventilation through sidewalls. These strategies allow good indoor thermal comfort in the main praying hall without depending on the air conditioning system. Similar to the Wooi Residence, indoor thermal comfort is also achieved through natural ventilation through various types of openings or ventilation gaps, and does not depend on the air conditioning system. Adopting passive design strategies and reducing dependency on the mechanical system, such as the air conditioning system, is one of the most workable solutions for modern buildings such as mosques and houses. If this simple practice is made common and accepted by all, it can reduce the dependency on high energy consumption and positively impact the environment.

\section{Conclusion}

There are at least 26 sustainable approaches in traditional Malaysian mosques and Malay houses. These sustainable approaches can also be found in the case studies of the modern house and mosque. The approaches can be used as an initial reference or guideline in designing new modern buildings in Malaysia, especially buildings with passive design strategies. Subsequently, if these approaches are appropriately applied in modern buildings, it can contribute toward more sustainable and greener development in Malaysia. This is proven based on the pilot study on the modern house and mosque. There is a crucial need to create awareness for all Malaysians on the benefits of these approaches, especially building designers.

\section{Acknowledgments}

The author would like to acknowledge and thank the Ministry of Education, Malaysia, for their support through the Fundamental Research Grant Scheme (FRGS/1/2020/TK0/UKM/02/26 - Roof Design in Controlling Mosque's Indoor Thermal Comfort).

\section{References}

A. Aziz. A, 2016. Masjid-Selected Mosques and Musollas in Malaysia, Kuala Lumpur, ATSA Architects Sdn Bhd.

Ashrifa Amir, Mohd. Farid Mohamed, Mohd Khairul Azhar Mat Sulaiman and Wardah Fatimah Mohammad Yusoff (2019), Assessment of Indoor Thermal Condition of a Low-Cost Single Story Detached House: A Case Study in Malaysia, Alam Cipta, Vol 12 (Special issue 1) Sept 2019: Emerging Green Building.

Elham Hosseini, Gurupiah Mursib, Raja Nafida Raja Shamninan (2016), Implementation of Traditional Malay Design Values in Contemporary Malay Houses, International Journal of Built 
Environment and Sustainability (IJBES), 3(2)/2016, 93-101.

Mastor Surat., Baharum, M. A., Usman, I. M. S., Musa, A. \& Tawil, N. 2012. Mengenalpasti Tahap Kesejahteraan Seni Bina Warisan Melayu Melalui Konsep Islam. Journal Design + Built, 5 .

Mastor Surat (2016a) Empat Teras Senibina yang boleh digunapakai dalam Gagasan Senibina Beridentiti Kebangsaan. Poster. Mastor Surat (2018), Cadangan Taksonomi Pengukuran Taraf Senibina Identiti Kebangsaan Malaysia. In N.A. Abdul Samad, M.F. Mohamed \& N. Ahmad @ Zakaria (Eds) Theme: National Architectural Identity, Proceeding of Conference on Regional Architecture and Built Environment 2018 (SeniBINA2018), Palm Garden Hotel Putrajaya, 13 - 14 November 2018. ISBN: 978-967-2224-18-1.

Mohd Farid Mohamed. (2018a). 21 Green Approaches in Traditional Malay House. IMPACT - Special Issue UKM-IIC2018, November 2018. ISSN 2289-9359, Universiti Kebangsaan Malaysia, Selangor.

Mohd Farid Mohamed. (2018b). Learning Traditional Malay House Through Working Drawing Course. K-Inovasi 2018 (Poster Presentation). Selangor. Muhammad Nushi Izahar, Mohd. Farid Mohamed (2018), Kelestarian Masjid Lama di Bandar Melaka (The Sustainability of Old Mosques in Malacca Town). In N.A. Abdul Samad, M.F. Mohamed \& N. Ahmad @ Zakaria (Eds) Theme: National Architectural
Identity, Proceeding of Conference on Regional Architecture and Built Environment 2018 (SeniBINA2018), Palm Garden Hotel Putrajaya, 13 - 14 November 2018. ISBN: 978-967-222418-1.

Nasir, A. H. 1985. Pengenalan Rumah Tradisional Melayu Semenangjung Malaysia, Kuala Lumpur, Darulfikir.

Nasir, A. H. 2004. Mosque Architecture in the Malay World, Bangi, Penerbit Universiti Kebangsaan Malaysia.

Nik Muhamad Amin Nik Muhammad Japlus, Mohd Farid Mohamed (2018), Pendekatan Hijau dalam Rekabentuk Rumah Tradisional Melaka di Kampung Morten. In N.A. Abdul Samad, M.F. Mohamed \& N. Ahmad @ Zakaria (Eds) Theme: National Architectural Identity, Proceeding of Conference on Regional Architecture and Built Environment 2018 (SeniBINA2018), Palm Garden Hotel Putrajaya, 13 - 14 November 2018. ISBN: 978-967-2224-18-1.

Yuan, L. J. (1987). The Malay house: Rediscovering Malaysia's indigenous shelter system, Pulau Pinang, Institut Masyarakat

Wan Teh, W. H. \& Nasir, A. H. (2011). The Traditional Malay House, Kuala Lumpur, Institut Terjemahan Negara Malaysia.

Wardah Fatimah Mohammad Yusoff, and Mohd Farid Mohamed (2017), Building Energy Efficiency in Hot and Humid Climate, in Encyclopedia of Sustainable Technologies. 2017, Elsevier Inc. 